\title{
The Political Red Queen
}

\author{
Giampaolo Garzarelli,giampaolo.garzarelli@gmail.com \\ Sapienza - University of Rome, Italy and University of the Witwatersrand, \\ South Africa \\ EmmaGalli,emma.galli@uniroma1.it \\ Sapienza - University of Rome, Italy
}

In 'The law of selection in the public economy as compared to the market economy', Professor Francesco Forte (1982) - contemporary doyen of the Scienza delle finanze tradition - extended an invitation to consider the public economy by means of evolutionary principles of selection. Not many replied to Professor Forte's invitation. This article is a delayed response to the invitation. Through a parallel with a metaphor from Lewis Carroll, it proposes the Political Red Queen hypothesis: politicians work to stay in power by weakening the evolutionary pressure under which they would otherwise naturally operate. A Political Red Queen exerts effort - runs, in the language of Carroll's original Red Queen metaphor - to make policy, promulgate laws, supply public and merit goods, and so on with the prime objective to survive by reducing the uncertainty linked to maintaining a political role. A Political Red Queen thus works to weaken 'natural' political selection. The Political Red Queen hypothesis is shown to hold, mutatis mutandis, for both democratic and non-democratic political environments. It can be viewed as incorporating a positive public choice nexus between politics-as-exchange and politics-as-power.

Key words evolution $\bullet$ knowledge constraint $\bullet$ political constraint $\bullet$ political survival $\bullet$ power $\cdot$ uncertainty

JEL codes: $\mathrm{B} 52 \cdot \mathrm{D} 00 \bullet \mathrm{D} 02 \cdot \mathrm{D} 70 \bullet \mathrm{H} 00$

To cite this article: Garzarelli, G. and Galli, E. (2020) The Political Red Queen, Journal of Public Finance and Public Choice, vol 35, no 1, 141-160,

DOI: $10.1332 / 251569120 X 15920660557733$

The relationship between evolutionary and economic thinking has a long history, with the two reciprocally influencing each other (for example, Schweber, 1977, 1980). Our main interest concerns one of the possible directions of influence: evolutionary thinking on economics.

Previous studies share our interest. Indeed, there is an entire research program known as evolutionary economics (for example, Witt, 2008; Nelson et al, 2018). Yet, evolutionary economics mainly directs attention at the private sphere (for example, Malerba, 2006); even when political aspects, such as power, are introduced, it is mostly in the context of trade-offs between firm and market (for example, Dosi, 
1995). The question addressed is usually something along the following lines: how can economic theorising, especially the one studying industry and the firm, benefit from evolutionary theorising? In a nutshell, the answer is that institutional, organisational and technological innovation ought to occupy centre stage because they are forms of variation in cultural artefacts that reflect adaptation under uncertainty through knowledge growth from learning, which is the core of any evolutionary explanation (Dosi and Nelson, 2018).

The broad narrative of this work fits within a variation of the more commonly addressed question in evolutionary economics. That is to say, we consider how theorising in public economics - by which we intend mostly its positive Public Choice variant with emphasis on the dynamics of politics-as-exchange and political entrepreneurship - can benefit from evolutionary thinking.

Schumpeter (2006 [1943]) is considered the father of evolutionary economics. Buchanan (1984) points out that Schumpeter should also be considered a pioneer for the study of public economics, especially in its post-constitutional (or positive) Public Choice manifestation. The influence of Schumpeter on Tullock is well known too (for example, Mueller, 2003: 2, n 1; Tullock, 2005 [1966])..$^{1}$ It is therefore somewhat surprising that, to date, theories of evolutionary economics and Public Choice have had little overlap. ${ }^{2}$

Still, one might recall in this connection two obliquely related works about policymaking: The science of "muddling through" (Linblom, 1959) and The Moon and the Ghetto (Nelson, 1977). In different ways, both these works emphasise the genuine 'second best' nature of policymaking when evolutionary considerations enter the scene. Moreover, they acknowledge the importance of the public sphere, especially politics, when studying policymaking. However, they ultimately emphasise that the main difficulty that policymakers face is knowledge limitations (see also the revisitations of Lindblom [1979] and Nelson [2011]).

Therefore, on the one side, we have Public Choice that considers politics as central but knowledge as secondary; on the other side, we have evolutionary economics that considers knowledge as central but politics as secondary. What we should really aim for is the centrality of both politics and knowledge: an approach to study the supply side of the public sphere that is informed by the existence of political as well as knowledge constraints. Of interest would be not just the constraints as such, but also their interplay. Indeed, the interplay can be interpreted as the positive Public Choice response to the importance of both politics-as-exchange and politics-as-power. ${ }^{3}$

Fortunately, we need not start from scratch when it comes to pursuing this suggested approach. There is a little-known 1982 contribution by Professor Francesco Forte that was significantly ahead of its time in terms of considering both constraints. ${ }^{4}$ We have in mind 'The law of selection in the public economy as compared to the market economy' (Forte, 1982), which appeared in the journal Public Finance/ Finances Publiques. Yet, Forte (1982) remains little used. ${ }^{5}$ In part, this work can be interpreted as an attempt to remedy this underuse by seeing Forte (1982) as a kind of first theoretical bridge.

The focus is on political survival. Specifically, the intent is to explore how politicians (but the logic can also apply to others in Public Choice roles, such as bureaucrats and legislators) attempt to maintain power. Similarly to Forte (1982), we consider how politicians adapt in both democracies and non-democracies (political environment or institutional setting). Thus, our fundamental unit of selection is the politician, 
with the purpose to think about the means of political survival within alternative institutional settings. How do politicians attempt to mould their political environment in order to stay in power?

Our answer is simple: irrespective of institutional setting (democratic or not), politicians - who, like other individuals, are rational - attempt to obviate 'natural' selection pressures by operating on political and knowledge constraints. In analogy with the Red Queen metaphor of Public Choice precursor Lewis Carroll (Charles Dodgson), we ultimately refer to the process that we point to as the Political Red Queen hypothesis. ${ }^{6}$ Like the Red Queen runs in order to stay in the same place, the Political Red Queen exerts effort to build parasitic (power) and symbiotic (exchange) relations in order to maintain a political role. ${ }^{7}$ It does so through (non-mutually exclusive) attempts to: (1) stay at their post; (2) move upwards; (3) place their political heirs. However, let us stress that analogy is not equivalence. Unlike the Red Queen, the Political Red Queen can stimulate and diffuse processes of variation. These processes can occur both when a Political Red Queen is successful, for example, new rules of the game (institutions) are introduced and then employed, and when it fails, for example, when policymaking is not successful. There is learning in both cases. ${ }^{8}$

Our argument connects, among others, to studies about party leadership control in legislatures (for example, Cox and McCubbins, 1993), political transactioncost manipulation (for example, Twight, 1994), bureaucratic drift (for example, McCubbins et al, 1987), and selectorate theory (Bueno de Mesquita et al, 2003). Yet, it differs from these and related studies about forms of rent-seeking (for example, Tullock, 2005) by adopting an explicit evolutionary lens for the study of the public economy. To survive - to reduce the uncertainty tied to the persistence of their influence - individuals populating the public economy are motivated to stay in office by maintaining, and ideally growing, power. The evolutionary lens leads to a conclusion about the public economy that is different from Alchian's (1950: 214, emphasis in original) well-known evolutionary point about the market economy, which asserts that survivors 'may appear to be those having adapted themselves to the environment, whereas the truth may well be that the environment has adopted them'. For a Political Red Queen, the primacy - which is not to say exclusivity - is adaptation to environment rather than environmental adoption.

\section{The law of selection in the public economy}

Forte (1982) is published the same year as Nelson and Winter's (1982) vastly influential neo-Schumpeterian book, An Evolutionary Theory of Economic Change. Furthermore, also like Nelson and Winter (1982), it is inspired by Alchian (1950), which became an overnight classic (for example, Alchian et al, 1996). Another important influence on Forte (1982) is the Italian Scienza delle finanze tradition (Buchanan, 1960), to which he himself belongs to as doyen. Moreover, a careful reading of Forte (1982) indicates that another useful influence of the Scienza delle finanze is the employment of dynamic reasoning (Pantaleoni, 1909, 2012).

Forte (1982) compares the public economy (under various institutional settings) to the market economy according to evolutionary principles. Its intent is to draw some novel lessons for how to more appropriately constrain the behaviour of individuals in public choice roles. Indeed, its motivation is that employing the law of selection can be useful to explaining, among other things, bureaucratic expansion, why demand 
for welfare services becomes more inelastic over time, why a state increasingly takes on more tasks and regulatory capture.

The law of selection is a basic evolutionary principle that goes back to R.A. Fisher's 'Fundamental Theorem of Natural Selection', which says that the 'rate of increase in fitness of any organism at any time is equal to its genetic variance in fitness at that time' (Fisher, 1930: 35, original emphasis removed). The Theorem is thus a nexus between natural selection and genetics by considering adaptation in statistical terms. ${ }^{9}$ For this reason, it has been subject to significant debate, interpretation and reconstruction. ${ }^{10}$ Nonetheless, it is (more or less) accepted (for example, Plutynski, 2006). One simple way to assert the law of selection in economic terms is, then, as follows: the rate of change in the average fitness of an entity (for example, the profitability of a firm) is in every point in time proportional to the variance of individual fitness (for example, profit differentials among competing firms). This means that a law-of-selection analysis considers how entities (including individuals, for example, entrepreneurs) of interest change over time and why some entities survive and others do not. The focus is thus on both ability to survive and comparisons among entities over time (for example, Metcalfe, 1998).

In the market economy, entities have an innate motivation to adapt because their viability is directly tied to their behaviour. In law-of-selection terms, all else being equal, entities that perform relatively better - that is, those that follow a cost-benefit paradigm - usually have a relatively higher likelihood of survival. ${ }^{11}$ However, in the public economy, the viability of misfits is more likely than in the market one because adaptation does not hinge strictly on economic principles; political principles apply as well. Politicians survive not necessarily just because they are good at their jobs, but also because of their ability to keep a low profile, conformism, party loyalty as well as party change, top-down obedience and so on. To put it in evolutionary lingo, the public economy is relatively more tolerant of survival behaviour tied to imitation, mimetism, mutation, parasitism and symbiotism. For this reason, the public economy may exhibit more misfits than the market economy (Forte, 1982: passim). ${ }^{12}$

The implication is that, over time, the public economy falls victim to a numbness of sorts: it becomes unresponsive to situations requiring adaptations ('irritations' in Professor Forte's words) that would otherwise keep it in shape. In essence, the public economy does not 'respond reactively' to situations because individual public choice agendas take priority. Therefore, it learns to live passively, leading to suboptimal performance through the use of survival strategies such as overspending and redistributive expansion. When irritations are not dealt with, the entire economy suffers (Forte, 1982: 239-42).

In the market economy, the absence of a reactive response to an irritation is instead less likely because, as we hinted, reward and loss are not separable. The ultimate message of Professor Forte's analysis then follows naturally: the law of selection operates better in the market than in the public economy. For this reason, the functioning of the latter ought to approximate as much as possible the functioning of the former. This applies a fortiori as the size of the public economy increases. ${ }^{13}$

For the construction of its message, Forte (1982) presents various propositions. The most relevant here are the following seven: 
P1. Politics-as-exchange persists in virtually all institutional settings (passim).

P2. Individuals creatively adapt to different institutional settings (228-34).

P3. Different institutional settings 'give rise to different kinds of selections and hence to a different "distribution" of resources and of life chances' (226).

P4. 'To behave economically does not mean to behave productively' (231).

P5. 'Immunization processes develop, weakening selection pressure' (231), or, alternatively stated, 'anybody having power naturally develops devices to resist ... selection’ (239).

P6. 'Different cultures develop in different environments for evolutionary purposes' (232).

P7. 'Competition in both private and public contexts is far from perfect' (232).

The seven propositions strongly permeate the pages that follow. Yet, the main thrust of our argument most closely relates to P5.

\section{Cost and choice}

In the spirit of Professor Forte's message, we consider - simplifying his analysis slightly - three ideal-typical institutional settings: the market, pure agency, and a group setting of wide scope (Buchanan, 1997). In a market, the individual bears the full cost of their choice; individuals pay directly for their mistakes. In pure agency, the individual will bear the cost indirectly as there is separation between choice and liability. In the case of a group setting of wide scope, the costs of choice have virtually no impact on the individual. Think of electoral behaviour: it is unlikely that a single vote will make the difference, which can render choice less responsible.

The setting of the market is accordingly one where choice and cost are strictly linked. The question to ask, then, is: what evolutionary insights can be gained in the cost-andchoice sense by considering other institutional settings? Public Choice, in fact, emphasises that different settings generate different opportunity costs of choice. Equally important, it emphasises that different settings differently tolerate or sustain the opportunity cost of choice (for example, Boettke and Candela, 2020). Both emphases are most commonly expressed with the Public Choice notion of concentrated benefits and dispersed costs. Moreover, the emphases can effectively be considered evolutionary, for they deal with issues about existence and survival linked with the indivisibility of choice and cost.

\section{The institutional setting matters}

There are many diverse situations that we face daily (economic, political and social) that influence our choice. Our responses to these situations do not usually follow a law of 'one size fits all'. We do not interact with a colleague in a committee in the same way that we interact with our children, and vice versa. It would not be 
evolutionarily clever to do so, for it would indicate an inability to adapt to changing institutional settings.

Repetition is economising when specific context is similar. In this case, behaviour can be usefully reproduced or, as evolutionary economists put it, 'routinised' (for example, Nelson and Winter, 1982; Cohen et al, 1996). Driving on the same side of the road, dinner-table etiquette that can be used at different restaurants and always placing house and car keys in the same spot of our home are paradigmatic illustrations of routines - of rules that are useful to stick to because they obviate conscious reasoning. However, in most cases, behaviour is not invariant. This means that most responses are usually tailored to the situation; they are often unique because of the function of the specific setting. What is routine in one setting may not be in another. However, in each similar setting, the result is the same, namely, expected responses that economise on deliberate thought (Garzarelli and Infantino, 2019).

The general point to underline is the following. Reasoning in terms of political and knowledge constraints suggests that the feasible set of behaviours is not just defined by income and other endowments (for example, natural resources, technology and time). Institutions - the rules of the game - play a role too because they can govern, discipline, enable, reinforce and suppress purposive behaviour. In a way, this means that they can innately exercise power over behaviour. Moreover, they can be designed and used by politicians to exercise and maintain their own power by channelling behaviour in particular directions. In turn, this entails that appropriately 'thorough analysis should include an examination of the institutional structure itself in a predictive explanatory sense' (Buchanan, 1999 [1968]: 5) - a point that Buchanan (2000) later also reasserts in more explicit evolutionary terms.

In a non-market setting, the role played by an institution is - like the origin of the institution itself - a matter of design. For example, in an agency relationship, such as the one depicted by a basic moral hazard model, the principal must make sure that the marginal contribution of the agent maximises not only the agent's expected utility, but also his own. In practice, the principal picks the agent's as well as his own marginal contribution to total output by designing an institution that tightens the feasible set of actions: an incentive contract. Principal and agent effectively operate as if one individual with the same knowledge, and this is essentially why the principal can align - 'exercise power efficiently' - the agent's incentives and optimise for both through the top-down contract.

The Scienza delle finanze root of Public Choice (for example, Pantaleoni, 1898; Fasiani, 1951) allows for the translation of this private sphere agency relation into ideal-typical public sphere scenarios (Forte, 1982; 2013; Wagner, 2017: 25-55). The useful ones for our purposes are the three autocracies (Tullock, 1987) of idealised despotism, authoritarianism and totalitarianism, and representative democracy. Except for idealised despotism, the institutional setting is a network of public choice relations that take place within and across a variety of organisations, such as cabinets, central planning committees, legislatures, political parties and unions, that is, in group settings of wide scope (de Viti de Marco, 1928).

The first translation is the most stylised. The principal is an idealised despot who exercises power without need for any supporting organisation. The despot coincides with the public sphere - it is the institution that caps the use of violence. Its existence is justified thanks to the ability to create order by providing protection through taxation (Olson, 1993). Since rent extraction through taxation is one with 
the despotic institutional set-up, there is effectively no knowledge problem, which, analogously to the private sphere agency relation, is equivalent to behaviour being aligned by construction.

This first translation surely gives us the most orderly control of violence. However, it also depicts the least feasible, the most 'blackboard' (Coase, 1998: 19), institutional setting. The usefulness of the idealised despot translation is, in fact, heuristic. Its value is given by the simplicity with which it introduces the basic logic behind public sphere survival: for the rational despot, the marginal cost of order ought to equal the share of the marginal product of labour - the tax.

\section{Authoritarianism}

A less stylised translation of the survival relation reveals that there are additional political interdependencies at play. That is to say, the supply of order through coercive taxation is an activity that requires inter-temporal compromises among many serving in public choice roles, regardless of institutional setting. Thus, the public sphere ought to be seen less as a monolith and more as the public choice network that it genuinely is.

For concreteness, consider China (Xu, 2011). Chinese political authoritarianism presents election structures and processes, most notably through the Organisation Department of the Party, for party members to elect subordinate public officials even if there is only one candidate to vote for. For example, this is the case of mayors. Once 'elected', a mayor is expected to govern by following the rule of local policy experimentation (for example, improving a city's tourism flow by building a new airport, a new highway and new hotels and museums). As the mayor responds directly to the party, the incentive is one of vertical political mobility: if the mayor performs the experiments as expected, then he can count on a promotion within the party ranks. What immediately comes to mind is the mayor surrounding himself with 'experts' (Koppl, 2018) to help with regards to how to proceed with policy experimentation. Architects, economists, engineers, lawyers, museum curators and so on, as well as politicians in subordinate positions and a variety of bureaucrats, are quickly called in to become personal advisors. The system thus generates parasitic compromises at the local and national levels.

The political constraint is binding in the Chinese and other authoritarian cases because the exchange relations have effectively been formalised through top-down design. Prima facie, the limited knowledge aspect seems binding too, in that the well-known motivation to perform policy experiments is knowledge limitations. In many ways, in fact, experiments are also a means to formally let local governments compete to discover novel ways of solving issues. One would therefore expect learning from experiments to be a fundamental component of a Chinese mayor's reward from political entrepreneurship. However, the limited knowledge problem is actually the handmaid of the political problem. It is acknowledged in importance, especially when motivating experimentation, but it is subservient in process and outcome: what matters more than learning from successful and unsuccessful policy trials is following the top-down-designed rule requiring the conduct of local policy experimentation.

For the city of Datong, in the Shanxi province of China, for instance, the policy experiments seem to be far from successful, and only add to China's bad loan situation. After five years in office (2008-13), Mayor Geng Yanbo achieved many 
important targets but his experiments did not fully achieve their objectives, with many experiments left unfinished. In fact, Mayor Geng left Datong an open construction site with more than 100 incomplete city redevelopment projects and a debt of US $\$ 3$ billion. Still - and this is what matters - he was able to make a vertical career move by becoming first, in 2013, Vice-mayor and soon thereafter Mayor of the capital and largest city of the province of Shanxi, Taiyuan. During his tenure as Mayor of Datong, Geng is also known for saying: we 'have our rules. Don't try to challenge the [central] government' (Zhao and Zhuo, 2015). ${ }^{14}$

The bottom line is that the lesson from mistake-ridden learning is not fully absorbed. However, if policy experimentation persists, then it must still serve a purpose - at least to someone. The evolutionary implication is that forces other than natural selection must be at play: the fact that error-making during policy trials does not necessarily guarantee adaptation from learning suggests that there are parasitic rents to be grabbed. The motive for local experimentation is largely in the interest of national political stability: a policy failure should not be allowed to spiral out of control, mainly because one does not want to produce excuses for citizens to voice their discontent about the regime. ${ }^{15}$ For this reason, policy experiments occur locally, where failures, even when resounding, manage to stay relatively contained. Persistence of the status quo through the political control of knowledge for the maintenance of order is the fundamental ingredient for the regime to not become evolutionary shark bait.

\section{Totalitarianism}

Deng Xiaoping understood very well that for the regime's survival it was necessary to place the political constraint above the knowledge one. ${ }^{16}$ Indeed, he saw it as a new Chinese revolution, as the pragmatic aspect of Maoism: the Chinese way to establish the primacy of praxis over theory. Coase and Wang (2012: 82) generalise the point well in a related context:

While the Chinese government in the 1980s was certainly more pragmatic and open to the idea of reform, this did not guarantee that the new policies they adopted were necessarily better than previous ones. As the Chinese leaders then proclaimed, 'reform should tolerate mistakes, but we cannot stand an absence of reform.' Deng Xiaoping himself probably emphasized more than anyone else the importance of learning from mistakes in the process of reform. However, many challenges remained. Not least of these was minimizing mistakes in learning and experimenting so as to maintain the political consensus behind reform, as well as relaxing political constraints without threatening the political legitimacy of the Party.

The passage from Mao to Deng (praxis above theory) can be seen as marking the Chinese passage from totalitarianism to authoritarianism. More broadly, the passage conceptually implies that the two political environments are variations of one another, with totalitarianism being an extreme form of authoritarianism. A totalitarian regime, in fact, tries to incorporate all aspects (economic, personal, political, religious and social) of life. Its ultimate objective is to de jure achieve the maintenance of a permanent revolution in a polity, often by also employing unpredictable violence towards a constructed enemy (for example, Fisichella, 1978). 
Although totalitarian teleology is more encompassing, what in practice applies to authoritarianism applies to totalitarianism too: the complete elimination of spontaneous relations, such as the Smithian 'propensity to truck, barter, and exchange one thing for another', in a situation of extreme asymmetry of power is not an occurrence. ${ }^{17}$ The similarity between authoritarianism and totalitarianism, from the impossibility to entirely purge emergent properties through design, does not mean equivalence between the two autocracies. The dynamics of politics-as-exchange are similar. However, those of knowledge linked to political entrepreneurship differ somewhat. On the one hand, the similarities allow us to directly enter, and to more succinctly deal with, issues of interest. On the other hand, the different dynamics require some attention.

Besides China under Chairman Mao, the most prominent totalitarian regimes in recent history are the Soviet Marxist regime of Stalin and the Nazi regime of Hitler (North Korea remains nebulous). The motivation and principles of operation are basically the same in both regimes, meaning that familiar ideological divides matter less than the pursuit of objectives (for example, Pellicani, 2009). Let us consider German Nazism (Breton and Wintrobe, 1986; Mixon, 2019).

In the Nazi regime, it was well understood that following orders from the top had priority over everything else. The survival strategy was simple and familiar: obey the orders and the political evolutionary pressure will be more lenient, even helping upwards progression. ${ }^{18}$ The vertical political exchange relation was therefore well defined, glued together by trust in the superior-subordinate relation. However, at the same time, the information content of the orders was intentionally ambiguous. Orders were given in vague terms, leaving the recipients - the bureaucratic subordinates relatively free about how to carry them out.

Related to the top-down order structure was the horizontal assignment one: the division of labour among individual bureaus. Like for the content of the orders, ambiguity was key here too: bureau task boundaries were intentionally not well designed, leading to redundancy in competence. Formal task ambiguity led to an overlap of task responsibility among the bureaus once the orders were released. Vague orders in combination with task ambiguity generated Schumpeterian political competition, where 'innovative' policies from experimentation by individual bureaus to solve 'totalitarian problems' were generously rewarded (with the usual: more support staff, new office, promotion and so on). There were, for example, many bureaus all competing to deliver a policy for the Final Solution, irrespective of cost and other 'priorities', such as winning the war.

The ambiguity of orders to subordinates helming bureaus and the ambiguity of task competence among the same bureaus served a function of disorientation. This double ambiguity is the knowledge dynamic behind the political institutionalisation of disorder. Routinisation of behaviour is, in most cases, difficult to achieve because change must be approved by the apex itself. In other words, there is resistance to blindly evolve beyond the state of affairs; evolution must be piloted towards the objective of the regime for everything to stay the same.

Like the authoritarian case, for totalitarianism, design does not just concern the ultimate end of constituent institutions, but also an attempt to bind all behaviour towards that ultimate end. However, unlike authoritarianism, learning from policy experiments through induced Schumpeterian competition is on a par with political 
objective. A dictator genuinely wants policy options, meaning that everyone is also kept on their toes for the interplay from political and knowledge dynamics.

\section{Representative democracy}

The law of selection suggests that politicians in representative democracy

are also ... dominated by the interest in obtaining and maintaining power. Those who do not have this interest are not likely to obtain political power, or, if by chance they emerge in the political game, will not last. Those who are unable to channel their passion for power in rational interests are likely to succumb to the competitors who have realized this rationalization. (Forte, 1984: 146, emphases in original)

Differently from autocracy, in representative democracy, political decision-making is delegated by means of genuine political elections. Elected representatives then take collective decisions through consensus. The way in which the consensus is reached varies; it depends on the agreed-upon rule. (Of course, the selection of representatives is also a question of rules: the electoral ones - a matter that we will return to.)

Public Choice normatively advances the Wicksellian unanimity (or near unanimity) rule. Unanimity (or near unanimity) in decision-making is what makes non-market settings operate analogously to market ones, where choice and cost are tightly coupled. The issue, of course, is that in the public economy, the same economics reasoning suggests that few post-constitutional decisions ought to be achieved under unanimity (or near unanimity) given the high costs attached to all reaching agreement. For this reason, post-constitutional majority rule still serves its pragmatic economising purpose.

In representative democracy, like autocracy, institutions are designed. However, unlike autocracy, the constituent rules of that design are more abstract (Hayek, 2013). Similarly to a market, there is no ultimate end. Rather, the rules are about conveying a general mode of acting sensibly under specific situations that cannot be fully predicted (Buchanan and Tullock, 1999[1962]: 78; Rawls, 1999: 118-68). For this reason, the way to deal with the uncertainty of everyday choices - adaptation - is by means of rules that do not deal with concrete scenarios. Democratic constitutions do not establish how collective decisions should be made in their representative assemblies, but often deputise such institutional responsibility to the assemblies themselves.

The committee system (for example, Shepsle, 1979), for instance, is an organisation that acts as a problem simplifier and problem solver by enabling the birth of coalitions. It overcomes cycling by creating incentives for vote trading, thus defining a postconstitutional game that leads to inter-temporal political equilibria. Uncertainty is still present. However, it has been 'reduced' to a level that can be managed (Simon, 1996: 183-216), generating repeated exchange that is often glued together by parasitic behaviour. At times, parasitism can be beneficial, as in the case of compromises for the supply of public goods; at other times, it can be detrimental, as in the case of compromises for the supply of public subsidies that bail out non-competitive firms (Wagner, 1997). However, the issue to underscore is that repeated exchange among politicians has repercussions: one continues (or, more precisely, one is allowed to continue) to play the political game insofar as there is reciprocity in behaviour; behavioural deviants are purged from the game. Reciprocity thus creates stability by 
creating predictability in expected response. Similar organisational and institutional solutions surface for other day-to-day majority decisions (for example, converting Bills into laws). ${ }^{19}$

Whereas autocracy governs and disciplines political exchange exogenously through coercion from agency, political exchange in democracy is governed and disciplined by the external effects tied to interdependency from quid pro quo behaviour. The decrease in coercion from agency in democracy is not synonymous with rudderless behaviour. External effects are the 'emergent power' that endogenously aligns behaviour through repeated exchange, naturally favouring political survival. As a result, the interdependent political behaviour of representative democracy de facto functions as unanimous (or near unanimous) even if there is de jure majority rule. To put it another way, one is unlikely to behave differently than expected because, as in the market, the cost of deviant behaviour falls directly on one's shoulders.

The process that we just described has two general uncertainty-reducing effects: first, the knowledge constraint is loosened because, through repeated exchange, the parties exchanging become less anonymous; and, second, the political constraint is tightened from the repercussions tied to the exchange interaction. From a lawof-selection perspective, the interplay of the two effects entails that the individual reproduces behaviour perceived to be successful through imitation and learning leading to political natural selection. The interplay of the two effects thus maintains the status quo during the play of the post-constitutional game.

It seems that an edge that representative democracy has over autocracy is that it is an institutional setting with less uncertainty overall. For example, we saw that Nazism was intentionally highly uncertain through planned disorder. In this way, the regime generated policy options but simultaneously imputed selective intervention to Hitler (social choice's unanimity through dictatorship manifesting in practice). Most autocracies are also more uncertain because their organisations (and institutions) do not usually last beyond their founders (or their families). In democracy, we instead have organisations (and institutions) that last beyond their founders (North et al, 2009).

At the same time, the empirical record indicates that autocrats 'are most successful at staying in power. Democratic leaders keep their jobs, on average, only about half as long as their autocratic counterparts, and for a much shorter time if they are compared with dictators who survive the first year or so in office' (Bueno de Mesquita and Smith, 2009: 167-8). These findings should not be puzzling considering that democracy presents legislative turnover and autocracy does not. Hence, democracy's ex ante defined legislative length also helps to reduce uncertainty, for the politician can better plan his future.

Therefore, democracy de jure limits the length of political life. Although it does not necessarily preclude the possibility of re-election in a subsequent legislature, it interrupts the post-constitutional routinisation for 'continuous' political survival. In this case, artificial selection through a legislative expiration date is of service, since it assures renewal of political power. Certainty of political turnover is another advantage of democracy over autocracy. We might say that the evolutionary blindness of representative democracy ought to ipso facto be greater than that of autocracy.

Note that these considerations about democracy imply that post-constitutional democratic politics exhibits two types of political games. On the one hand, as already seen, there are games that are played after elections. On the other hand, there are 
games played between elections, which generate two artificial mechanisms for political survival - one positive and the other negative.

The positive mechanism regards increasing chances of election (or re-election) through investment in political competence and personal attributes. Such investment would, for example, improve competitive advantage and solidify reputation. The politician would then signal these improvements during the electoral campaign, adapting the signal to the median voter as the election date approaches through, for example, participation in public debates, social media and talk shows. The negative artificial mechanism for political survival hinges on rent-seeking activities undertaken to show loyalty to the party; for example, investing in long-term horizontal and (especially) vertical political relationships that can lead to electoral candidature or re-candidature and prestigious political appointments.

The negative and positive mechanisms can also mean political survival through political legacy, or, in biological terminology, offspring. An incumbent politician may invest in building his survival by means of possible political heirs. Indeed, the extension of political life, and attempts to obtain extension in political life, through protégés is often seen in democracy, even within the same family (for example, Bush, Clinton and Kennedy). There are also failures to extend political life through legacy, such as that of Berlusconi, who struggles to find a political heir.

The two mechanisms usually coexist. However, an electoral rule can impact which one dominates. In a proportional system with a blocked list, for example, the probability of election (or re-election) mostly depends on the relative position on the list (first choice, second choice and so on), which mostly results from loyalty to the party rather than competitiveness and reputation. In a proportional system with an open list, voters instead operate on the selection of the politician, which mostly results from competitiveness and reputation rather than party loyalty.

Besides the positive and negative post-constitutional mechanisms of political survival between elections, there can also be the mechanism of reforming electoral rules during the post-constitutional game. This mechanism would need a high majority, such as at least near unanimity, to approximate the decision-making of the pre-constitutional stage. For instance, former Italian Prime Minister Matteo Renzi promoted a reform of the electoral rule - Italian Law 6 May 2015, no. 52 - during his incumbency (February 2014-December 2016). The intent of the law, popularly known as the Italicum, was designed to guarantee the victory of Renzi's party (Partito Democratico) in the next election. The Italicum was never employed, and was ultimately repealed for constitutional reasons. However, it represented another artificial selection mechanism to maintain the status quo, also in terms of surviving through political heirs.

\section{Conclusion}

This work takes its cues from a vanguard but somewhat neglected contribution by Professor Francesco Forte about the explicit application of evolutionary principles of selection to the supply side of the public economy. It does so through an analysis that combines evolutionary economics and Public Choice to consider political survival mechanisms under different institutional settings (idealised despotism, authoritarianism, totalitarianism and representative democracy). Idealised despotism, the most stylised setting, is useful for heuristic purposes: it sets the stage by informing us that the rational politician employs cost-benefit analysis to attempt to survive. 
Table 1: Summarising the Political Red Queen hypothesis

\begin{tabular}{|l|l|l|l|}
\hline & Authoritarianism & Totalitarianism & $\begin{array}{l}\text { Representative } \\
\text { Democracy }\end{array}$ \\
\hline Rules & Specific & Specific & Abstract \\
\hline Political stability & Exogenous (agency) & Exogenous (agency) & $\begin{array}{l}\text { Endogenous (tight } \\
\text { coupling of cost } \\
\text { and choice) }\end{array}$ \\
\hline Political turnover & $\begin{array}{l}\text { Unknown } \\
\text { (No formal } \\
\text { expiration date) }\end{array}$ & $\begin{array}{l}\text { Unknown } \\
\text { (No formal } \\
\text { expiration date) }\end{array}$ & $\begin{array}{l}\text { Known } \\
\text { (Formal expiration } \\
\text { date) }\end{array}$ \\
\hline Institutions/organisations & Temporary & Temporary & Long-lived \\
\hline Political constraint & $\begin{array}{l}\text { Exogenously } \\
\text { tightened }\end{array}$ & $\begin{array}{l}\text { Exogenously } \\
\text { loosened }\end{array}$ & $\begin{array}{l}\text { Endogenously } \\
\text { loosened }\end{array}$ \\
\hline loosened & $\begin{array}{l}\text { Exogenously } \\
\text { tightened }\end{array}$ & $\begin{array}{l}\text { Endogenously } \\
\text { tightened }\end{array}$ \\
\hline Law of selection & Artificial & $\begin{array}{l}\text { Post-election: } \\
\text { artificial and natural } \\
\text { Between-election: } \\
\text { artificial, the nature } \\
\text { of which can } \\
\text { vary according to } \\
\text { electoral rule }\end{array}$ \\
\hline
\end{tabular}

The other institutional settings, which are the central substantive focus, are instead interpreted in less stylised terms, that is, as networks of public choice relations. Their law-of-selection analysis hinges on the concomitant consideration of both knowledge and political constraints. A Political Red Queen works to stay in power by attempting to artificially control the natural evolutionary pressure of these constraints. It exerts effort to make policy, promulgate laws, supply public and merit goods and so on with the prime objective to survive by reducing the uncertainty linked to maintaining political influence through such mechanisms as changing the rules of the game, keeping incumbency, moving upwards, paving the way for a protégé, policy experimentation and quid pro quo. The institutional setting influences how selection can be manipulated in terms of the appropriate mix between these politicsas-exchange and politics-as-power mechanisms.

Like the original Red Queen, our hypothesis is a metaphor. It is not a literal description of the real-world phenomena that we consider, but it is useful to describe how politicians in different institutional settings try to survive. This also means that: (1) an institutional setting can present many Political Red Queens at once; and (2) the characteristics of the institutional setting can influence the attributes and behaviour of a Political Red Queen. In brief, Political Red Queen variants can populate the same institutional setting and Political Red Queen variants can populate different institutional settings. Table 1 summarises the Political Red Queen hypothesis in relation to the attributes of the institutional setting and the resultant law of selection.

As befits an often-employed type of evolutionary economics theorising, this work is appreciative: its framework for inquiry is informal, used intuitively and commonsense empirical (Nelson and Winter, 1982: 46). This also means that, at times, our narrative presents some degree of linear dependence between methodological and theoretical levels. Future studies should more crisply isolate the two levels, also with the intent to empirically test aspects of the Political Red Queen hypothesis. 


\section{Acknowledgements}

We thank Silvia Fedeli, Francesco Forte, Lorenzo Infantino and two referees for useful feedback.

\section{Notes}

1 Tullock, of course, was also interested in biology. However, his principal passion in this regard was in another direction of influence: the usefulness of applying economic theory to biology - bioeconomics. For a sampling, see the classic Tullock (1971a, 1994) and the less-known, but equally fascinating, Tullock (1971b).

2 Most of the overlap can arguably be found in Witt (1992), Breton (1996), Wohlgemuth (2002), Pelikan and Wegner (2003), Mueller (2004), Garzarelli (2006), Wagner (2010), Fedeli, Forte and Leonida (2014), Albrecht et al (2018) and Garzarelli and Keeton (2018). On the fiscal sociology of Schumpeter, see also Musgrave (1992).

3 See Buchanan's (1987: 246) Nobel lecture on this interplay in the normative domain of Public Choice. From political science, Moe (for example, 2005), of course, has long advocated for a positive position about the political importance of both exchange and power.

4 Professor Forte was fundamental in assisting Buchanan to become better acquainted with the Italian tradition of Scienza delle finanze during Buchanan's 1955-56 visit to Italy as FulbrightVisiting Professor. Later (1959-61), Forte was a member of the Thomas Jefferson Center for Studies in Political Economy and Social Philosophy (University of Virginia [UVA], Charlottesville) thanks to an invitation by Buchanan. In 1961, Professor Forte declined UVA's promotion from Associate to Full Professor (supported by both Buchanan and Ronald Coase) after accepting to succeed Luigi Einaudi in the Public Finance Chair at the University of Turin (at Einaudi's asking). For a comprehensive biography of Professor Forte's impressive academic and other accomplishments, see Fedeli (2018); for a list of Professor Forte's numerous publications, see the 'Electronic supplementary material' by Elena Costarelli that is linked to Fedeli (2018). See also Catanoso and Fedeli (2020) - the 'Introduction' to this special issue.

5 Web of Science and IDEAS both report five citations each (but the citing documents do not all match) and the broader net cast by Google Scholar reports 16 citations, which include all citations from Web of Science and IDEAS except for one. We can thus consider 17 to be a good approximation of total citations of Forte (1982), making the average gross citation 0.45 per year; if one excludes self-citations, the net average citation per year is 0.32 .

6 One of the present authors (Garzarelli) learned about the economic usefulness of the metaphor of the Red Queen a long time ago - in the late 1990s from Khalil (1997). However, we both now suspect that the metaphor will become increasingly popular in economics (see Acemoglu and Robinson, 2019: 33-73 and passim). Of course, others also found it useful in other economics contexts (for example, Olmstead and Rhode, 2002). The original introduction of the metaphor in 'science' is Van Valen (1973).

7 Carroll's (2009 [1865/1871]:145) original formulation in Through the Looking Glass and What Alice Found There is as follows: "Well, in our country," said Alice, still panting a little, "you'd generally get to somewhere else - if you run very fast for a long time, as we've been doing." "A slow sort of country!" said the Queen. "Now, here, you see, it takes all the running you can do, to keep in the same place. If you want to get somewhere else, you must run at least twice as fast as that!"' On the importance of Charles Dodgson (aka Lewis Carroll) for Public Choice, see Black (for example, 1998: 223-70). 
8 On learning from success and failure, see Garzarelli and Keeton (2018).

9 One finds this observation often repeated and Levallois (2009) argues that it holds true for Alchian (1950) as well.

${ }^{10}$ See, among others, Edwards (1994), who also suggests that the origin of the idea derives from Adam Smith's (1776) Wealth of Nations.

11 This is not tantamount to saying that only the best survive - the fit criterion is relative, not absolute. Uncertainty still holds: "What really counts is the various actions actually tried, for it is from these that "success" is selected, not from some set of perfect actions. The economist may be pushing his luck too far in arguing that actions in response to changes in environment and changes in satisfaction with the existing state of affairs will converge as a result of adaptation or adoption toward the optimum action that should have been selected, if foresight had been perfect' (Alchian, 1950: 220). Therefore, Dr Pangloss is not at work.

12 A fortiori, then, Dr Pangloss is not at work in the public economy.

${ }^{13}$ Professor Forte is still interested in how the law of selection applies to the public economy (see, among others, Fedeli and Forte, 2013a; 2013b; 2013c; Fedeli et al, 2014; 2020). However, in these more recent works, the analysis has shifted from the politician to political elites (for instance, Kautsky, Michels, Mosca, Pareto).

${ }^{14}$ In 2019, Geng 'resigned' as Mayor of Taiyuan (see: www.jqknews.com/news/126807Geng_Yanbo_the_mayor_of_Taiyuan_who_left_office_to_do_this_has_been_called_ Li_Dakang_in_the_real_world.html).

${ }^{15}$ See:www.csmonitor.com/World/Asia-Pacific/2016/0604/Inside-China-s-hard-drive

16 Deng Xiaoping, 'Interview with Mike Wallace of 60 Minutes', 2 September 1986, available at: https://china.usc.edu/deng-xiaoping-interview-mike-wallace-60-minutessept-2-1986

17 See, for example, Radford (1945) and Skarbeck (2014), and compare Simmel (2009 [1908]: 130): 'the elimination of all spontaneity within a situation of subordination is in reality' not as common as popularly thought; even 'in the most oppressive and cruel relations of subjugation, there always yet remains a substantial measure of personal freedom'; the 'relationship of dominance and subordination annihilates the freedom of the subjugated only in the case of direct physical coercion.... It can increasingly narrow the circle of external influences in which it realizes itself, but, except for the use of physical coercion, never to the point of completely disappearing'; social interaction 'exists even in ... cases of dominance and subordination'.

18 This is what biology would refer to as 'orthogenesis', or evolutionary progress - after all, it is only natural for a teleological institutional setting to be teleological for the members of its machinery too.

${ }^{19}$ Shepsle and Weingast (2012) provide a useful overview of many institutional and organisational solutions (agenda setting, partisan thinking, universalism and so on) that emerge to reduce uncertainty under majority rule.

\section{Conflict of interest}

The authors declare that there is no conflict of interest.

\section{References}

Acemoglu, D. and Robinson, J.A. (2019) The Narrow Corridor: States, Societies and the Fate of Liberty, UK:Viking, London. 
Albrecht, B.C., Hendrickson, J.R. and Salter, A.W. (2018) Evolution, uncertainty, and the asymptotic efficiency of policy, Available at: https://papers.ssrn.com/sol3/ papers.cfm?abstract_id $=3251917$

Alchian, A.A. (1950) Uncertainty, evolution and economic theory, Journal of Political Economy, 58(3): 211-21. doi: 10.1086/256940

Alchian, A.A., Buchanan, J.M., Demsetz, H., Leijonhufvud, A., Lott, J.R., Jr, Sharpe, W.F. and Topel, R.H. (1996) In celebrating Armen A.Alchian's 80th birthday: living and breathing economics, Economic Inquiry, 34(3): 412-26. doi: 10.1111/j.14657295.1996.tb01386.x

Black, D., with Newing, R.A. (1998) The Theory of Committees and Elections and Committee Decisions with Complementary Valuations, rev 2nd edn, in I. McLean, A. McMillan and B.L. Monroe; Foreword by R.H. Coase (eds) New York, NY: Springer Science + Business Media.

Boettke, P.J. and Candela, R.A. (2020) Where Chicago meets London: James M. Buchanan, Virginia political economy, and cost theory, Public Choice, https://doi. org/10.1007/s11127-020-00796-4

Breton, A. (1996) Competitive Governments: An Economic Theory of Politics and Public Finance, New York, NY: Cambridge University Press.

Breton, A. and Wintrobe, R. (1986) The bureaucracy of murder revisited, Journal of Political Economy, 94(5): 905-26. doi: 10.1086/261417

Buchanan,J.M. (1960) 'La scienza delle finanze': the Italian tradition in fiscal theory, in J.M. Buchanan (ed) Fiscal Theory and Political Economy, Chapel Hill, NC: University of North Carolina Press, pp 24-74.

Buchanan,J.M. (1984) Schumpeter as precursor to non-constitutional public choice, Journal of Public Finance and Public Choice, 2(1): 51-3. doi: 10.1332/251569298X1 5668907116751

Buchanan,J.M. (1987) The constitution of economic policy, American Economic Review, 77(3): 243-50.

Buchanan, J.M. (1997) La scelta individuale nei ruoli decisionali, in A.M. Petroni and R. Viale (eds) Individuale e Collettivo: Decisione e Razionalità, Milan: Raffaello Cortina, pp 83-99 (Italian translation of Individual choice behavior in private, agency, and collective decision rules).

Buchanan, J.M. (1999 [1968]) The Demand and Supply of Public Goods. The Collected Works of James M. Buchanan, vol 5, (Foreword by G. Brennan), Indianapolis, IN: Liberty Fund.

Buchanan, J.M. (2000) Group selection and team sports, Journal of Bioeconomics, 2(1): 1-7. doi: 10.1023/A:1010082906001

Buchanan, J.M. and Tullock, G. (1999 [1962]) The Calculus of Consent: Logical Foundations of Constitutional Democracy. The Collected Works of James M. Buchanan, vol 3, (Foreword by R. D. Tollison), Indianapolis, IN: Liberty Fund.

Bueno de Mesquita,B. and Smith,A. (2009) Political survival and endogenous institutional change, Comparative Political Studies, 42(2):167-97. doi:10.1177/0010414008323330

Bueno de Mesquita, B., Smith, A., Siverson, R.M. and Morrow, J.D. (2003) The Logic of Political Survival, Cambridge, MA: MIT Press.

Carroll, L. (2009 [1865/1871]) Alice's Adventures in Wonderland and Through the Looking Glass and What Alice Found There, New York, NY: Oxford University Press (Oxford World's Classics). 
Catanoso, P. and Fedeli, S. (2020) The theory and practice of public choice. Introduction to the special issue in honour of Francesco Forte, Journal of Public Finance and Public Choice, 35(1): 3-8. doi: 10.1332/251569120X15929333159379.

Coase, R.H. (1998) The Firm, the Market, and the Law, Chicago, IL: University of Chicago Press.

Coase, R.H. and Wang, N. (2012) How China Became Capitalist, New York, NY: Palgrave Macmillan.

Cohen, M.D., Burkhart, R., Dosi, G., Egidi, M., Marengo, L., Warglien, M. and Winter, S. (1996) Routines and other recurring action patterns of organizations: contemporary research issues, Industrial and Corporate Change, 5(3): 653-98. doi: 10.1093/icc/5.3.653

Cox, G.W. and McCubbins, M.D. (1993) Legislative Leviathan: Party Government in the House, 2nd edn, New York, NY: Cambridge University Press.

deViti de Marco,A. (1928) I Primi Principii dell'Economia Finanziaria, Roma: Sanpaolesi.

Dosi, G. (1995) Hierarchies, markets and power: some foundational issues on the nature of contemporary economic organizations, Industrial and Corporate Change, 4(1):1-19.

Dosi, G. and Nelson, R.R. (2018) Technological advance as an evolutionary process, in R.R. Nelson, G. Dosi, C. Helfat,A. Pyka, P.P. Saviotti, K. Lee, K. Dopfer, F. Malerba and S. Winter (eds) Modern Evolutionary Economics: An Overview, Cambridge: Cambridge University Press, pp 35-84.

Edwards, A.W.F. (1994) The fundamental theorem of natural selection, Biological Reviews, 69(4): 443-74. doi: 10.1111/j.1469-185X.1994.tb01247.x

Fasiani, M. (1951) Principii di Scienza delle Finanze, vols I and II, 2nd edn, Torino: Giappichelli.

Fedeli, S. (2018) Public choice as positive economics. Introduction to the special issue honoring Francesco Forte, Public Choice, 177(3/4: Special issue: honoring Francesco Forte): 189-97. doi: 10.1007/s11127-018-0578-5

Fedeli, S. and Forte, F. (2013a) The Pareto sociological theory of the elites and the Italian Parliament (1861-1928), in J. Backhaus (ed) Essentials of Fiscal Sociology (Series: Finanzsoziologie - vol 5), Frankfurt: Peter Lang Pub Inc, pp 281-308.

Fedeli, S. and Forte, F. (2013b) A survival analysis of the circulation of the political elites governing Italy from 1861 to 1994, in J. Backhaus (ed) Essentials of Fiscal Sociology (Series: Finanzsoziologie - vol 5), Frankfurt: Peter Lang Pub Inc, pp 309-35.

Fedeli, S. and Forte, F. (2013c) In search of the laws of access and survival of the members of the Italian Parliament in relation to their party affiliation (1946-2011), in J. Backhaus (ed) Essentials of Fiscal Sociology (Series: Finanzsoziologie - vol 5), Frankfurt: Peter Lang Pub Inc, pp 447-69.

Fedeli, S., Forte, F. and Leonida, L. (2014) The law of survival of the political class: an analysis of the Italian Parliament (1946-2013), European Journal of Political Economy, 35: 102-21. doi: 10.1016/j.ejpoleco.2014.05.001

Fedeli, S., Forte, F. and Leonida, L. (2020) Opportunism and MPs' chances of reelection. An analysis of political transformism in the Italian Parliament, working paper.

Fisher, R.A. (1930) The Genetical Theory of Natural Selection, Oxford: Clarendon.

Fisichella, D. (1978) Analisi del Totalitarismo, 2nd edn, Messina-Firenze: Casa Editrice G. D'Anna.

Forte, F. (1982) The law of selection in the public economy as compared to the market economy, Public Finance/Finances Publiques, 37(2): 224-45. 
Forte, F. (1984) Democracy as a public good: efficiency versus effectiveness, Journal of Public Finance and Public Choice, 2(3): 143-54. doi: 10.1332/251569298X15668 907116904

Forte, F. (2013) On James Buchanan's public choice enterprise, Journal of Public Finance and Public Choice, 31(1-3): 61-75. doi: 10.1332/251569213X15664519748541

Garzarelli, G. (2006) Cognition, incentives, and public governance: laboratory federalism from the organizational viewpoint, Public Finance Review, 34(3): 235-57. doi: 10.1177/1091142105285593

Garzarelli, G. and Keeton, L. (2018) Laboratory federalism and intergovernmental grants, Journal of Institutional Economics, 4(5): 949-74. doi: 10.1017/S1744137417000595

Garzarelli, G. and Infantino, L. (2019) An introduction to Expert Failure: lessons in socioeconomic epistemics from a deeply embedded method of analysis, Cosmos + Taxis, 7(1/2): 2-7.

Hayek, F.A.V. (2013) Law, Legislation and Liberty. A New Statement of the Liberal Principles of Justice and Political Economy, London: Routledge (first published as three books in 1973, 1976 and 1979).

Khalil, E.L. (1997) The red queen paradox: a proper name for a popular game, Journal of Institutional and Theoretical Economics, 153(2): 411-15.

Koppl, R. (2018) Expert Failure, New York, NY: Cambridge University Press.

Levallois, C. (2009) One analogy can hide another: physics and biology in Alchian's 'economic natural selection', History of Political Economy, 41(1): 163-81. doi: 10.1215/00182702-2008-041

Lindblom, C.E. (1959) The science of 'muddling through', Public Administration Review, 19(2): 79-88. doi: 10.2307/973677

Lindblom, C.E. (1979) Still muddling, not yet through, Public Administration Review, 39(6): 517-26. doi: 10.2307/976178

Malerba, F. (2006) Innovation and the evolution of industries, Journal of Evolutionary Economics, 16(1/2): 3-23. doi: 10.1007/s00191-005-0005-1

McCubbins, M.D., Noll, R.G. and Weingast, B.R. (1987) Administrative procedures as instruments of political control, Journal of Law, Economics, and Organization, 3(2): 243-77.

Metcalfe, S.J. (1998) Evolutionary Economics and Creative Destruction, London: Routledge.

Mixon, F.G. (2019) A Terrible Efficiency: Entrepreneurial Bureaucrats and the Nazi Holocaust, Switzerland: Palgrave Pivot, Springer Nature Switzerland AG.

Moe,T.M. (2005) Power and political institutions, Perspectives on Politics, 3(2):215-33. doi: 10.1017/S1537592705050176

Mueller, D.C. (2003) Public Choice III, New York, NY: Cambridge University Press.

Mueller,D.C. (2004) Models of man: neoclassical, behavioral and evolutionary, Politics, Philosophy and Economics, 3(1): 59-76. doi: 10.1177/1470594X04039982

Musgrave, R.A. (1992) Schumpeter's crisis of the tax state: an essay in fiscal sociology, Journal of Evolutionary Economics, 2(2): 89-113. doi: 10.1007/BF01193535

Nelson, R.R. (1977) The Moon and the Ghetto:An Essay on Policy Analysis, New York, NY:W.W. Norton.

Nelson, R.R. (2011) The Moon and the Ghetto revisited, Science and Public Policy, 38(9): 681-90. doi: 10.1093/scipol/38.9.681

Nelson, R.R. and Winter, S. (1982) An Evolutionary Theory of Economic Change, Cambridge, MA:The Belknap Press of Harvard University Press. 
Nelson, R.R., Dosi, G., Helfat, C., Pyka,A., Saviotti, P.P., Lee, K., Dopfer, K., Malerba, F. and Winter, S. (2018) Modern Evolutionary Economics: An Overview, Cambridge: Cambridge University Press.

North, D.C., Wallis, J.J. and Weingast, B.R. (2009) Violence and Social Orders: A Conceptual Framework for Interpreting Recorded Human History, New York, NY: Cambridge University Press.

Olmstead,A.L. and Rhode, P.W. (2002) The red queen and the hard reds: productivity growth in American wheat, 1800-1940, Journal of Economic History, 62(4): 929-66. doi: 10.1017/S0022050702001602

Olson, M. (1993) Dictatorship, democracy, and development, American Political Science Review, 87(3): 567-76. doi: 10.2307/2938736

Pantaleoni, M. (1898) An attempt to analyze the concept of 'strong and weak' in their economic connections, Economic Journal, 8(30): 183-205. doi: 10.2307/2957359

Pantaleoni, M. (1909) Di alcuni fenomeni di dinamica economica, Giornale degli Economisti (serie seconda), 39(20): 211-54.

Pantaleoni, M. (2012) Some phenomena of economic dynamics, Giornale degli Economisti e Annali di Economia (nuova serie), 71(125, No. 2/3): 113-48. Translation of Pantaleoni (1909) by S. D'Amico.

Pelikan, P. and Wegner, G. (eds) (2003) The Evolutionary Analysis of Economic Policy, Cheltenham: Edward Elgar.

Pellicani, L. (2009) Lenin e Stalin: I Due Volti del Totalitarismo, Soveria Mannelli: Rubbettino.

Plutynski,A. (2006) What was Fisher's fundamental theorem of natural selection and what was it for?, Studies in History and Philosophy of Science Part C: Studies in History and Philosophy of Biological and Biomedical Sciences, 37(1): 59-82. doi: 10.1016/j. shpsc.2005.12.004

Radford, R.A. (1945) The economic organization of a P.O.W. camp, Economica, 12(48): 189-201. doi: $10.2307 / 2550133$

Rawls, J. (1999) A Theory of Justice, Revised Edition, Cambridge, MA: The Belknap Press of Harvard University Press.

Schumpeter,J.A. (2006 [1943]) Capitalism, Socialism and Democracy (New Introduction by R. Swedberg), London: Routledge.

Schweber, S.S. (1977) The origin of the 'origin' revisited, Journal of the History of Biology, 10(2): 229-316. doi: 10.1007/BF00572644

Schweber, S.S. (1980) Darwin and the political economists: divergence of character, Journal of the History of Biology, 13(2): 229-316.

Shepsle, K. (1979) Institutional arrangements and equilibrium in multidimensional voting models, American Journal of Political Science, 23(1):27-59. doi:10.2307/2110770

Shepsle, K. and Weingast, B.R. (2012) Why so much stability? Majority voting, legislative institutions, and Gordon Tullock, Public Choice, 152(1/2:The intellectual legacy of Gordon Tullock): 83-95. doi: 10.1007/s11127-011-9853-4

Simmel, G. (2009 [1908]) Sociology: Inquiries Into the Construction of Social Forms (trans and ed A.J. Blasi, A.K. Jacobs and M. Kanjirathinkal; Introduction by H.J. Helle), Leiden, The Netherlands: Koninklijke Brill NV.

Simon, H.A. (1996) The Sciences of the Artificial, 3rd edn, Cambridge, MA: MIT Press.

Skarbeck, D. (2014) The Social Order of the Underworld. How Prison Gangs Govern the American Penal System, New York, NY: Oxford University Press. 
Smith, A. (1776) An Inquiry Into the Nature and Causes of the Wealth of Nations (two volumes), Indianapolis: Online Liberty Fund Edition: http://www.econlib.org/ library/Smith/smWN.html. Accessed July 4, 2020.

Tullock, G. (1971a) The coal tit as a careful shopper, American Naturalist, 105(941): 77-80. doi: 10.1086/282704

Tullock, G. (1971b) Biological externalities, Journal of Theoretical Biology, 33(3):565-76. doi: 10.1016/0022-5193(71)90097-X

Tullock, G. (1987) Autocracy, Dordrecht: Springer Science + Business Media.

Tullock, G. (1994) The Economics of Non-human Societies, Tucson, AZ: Pallas Press.

Tullock, G. (2005 [1966]) The Organization of Inquiry. The Selected Works of Gordon Tullock, vol 3, (ed and Introduction by C.K. Rowley), Indianapolis, IN: Liberty Fund.

Tullock, G. (2005) The Rent Seeking-society. The Selected Works of Gordon Tullock, vol 5, (ed and Introduction by C.K. Rowley), Indianapolis, IN: Liberty Fund.

Twight, C. (1994) Political transaction-cost manipulation: an integrating theory, Journal of Theoretical Politics, 6(2): 189-216. doi: 10.1177/0951692894006002003

Van Valen, L. (1973) A new evolutionary law, Evolutionary Theory, 1: 1-30.

Wagner, R.E. (1997) Parasitical political pricing, economic calculation, and the size of government: variations on a theme by Maffeo Pantaleoni, Journal of Public Finance and Public Choice, 15(2/3): 135-46. doi: 10.1332/251569298X15668907782888

Wagner, R.E. (2010) Mind, Society, and Human Action:Time and Knowledge in a Theory of Social Economy, London and New York, NY: Routledge.

Wagner, R.E. (2017) James M. Buchanan and Liberal Political Economy: A Rational Reconstruction, London: Lexington Books.

Witt, U. (1992) The endogenous public choice theorist, Public Choice, 73(1): 117-29. doi: $10.1007 / \mathrm{BF} 00142920$

Witt, U. (2008) What is specific about evolutionary economics?, Journal of Evolutionary Economics, 18(5): 547-75. doi: 10.1007/s00191-008-0107-7

Wohlgemuth, M. (2002) Evolutionary approaches to politics, Kyklos, 55(2): 223-46. doi: 10.1111/1467-6435.00184

$\mathrm{Xu}, \mathrm{C} .(2011)$ The fundamental institutions of China's reforms and development, Journal of Economic Literature, 49(4): 1076-151. doi: 10.1257/jel.49.4.1076

Zhao, Qi (Producer) and Zhuo, Hao (Director) (2015) The Chinese Mayor [Datong], documentary, China: Zhao Qi Films (also broadcast on 10 February 2015 as part of BBC's documentary series Storyville, under the title 'Bulldozers, paving stones and power: the Chinese mayor'). 